DOI: $10.15587 / 2706-5448.2021 .240260$

Article type «Reports on Research Projects»

\section{Anatolii Novak, Eduard Fesenko, Yevhen Pavlov}

\title{
IMPROVEMENT OF TECHNOLOGICAL PROCESSES FOR MINING SOLID MINERAL RESOURCES
}

The object of research is the technological processes of the development of deposits and the extraction of solid minerals by underground and open-pit methods. The improvement of technological processes is achieved through the use of existing original technical solutions, which are currently advisable to use in practice. The work is aimed at increasing the efficiency of explosive energy use, improving the technological processes of mining operations in coal mines and open pits of mining enterprises.

In the course of the study, an analysis of technical literature on mining topics was used, a search for copyright certificates for inventions and patents on the same topic was carried out. There was a search for innovative solutions that are expedient to apply at the present time. In the course of the analysis, the work shows ideas, methods of coal mining, systems for the development of coal seams, methods of destruction of rocks, microbiological reclamation and other new technologies and devices. The most promising technologies have been proposed for in-depth study, implementation and use in appropriate mining and geological conditions. The proposed technologies, for various reasons, have not yet found wide practical application at mining enterprises. Due to the application of the proposed technical solutions and technologies in practice in the conditions of existing coal mines and open pits, significant economic, environmental and financial effects can be obtained.

This study was carried out in order to bring to a wide circle of specialists technical solutions that can contribute to a significant improvement in the technology of mining solid minerals, both in underground and open-pit mining all over the world.

Keywords: systems of underground mining of coal seams, interference of blast waves, open-pit mining.

\section{How to cite}

Novak, A., Fesenko, E., Pavlov, Y. (2021). Improvement of technological processes for mining solid mineral resources. Technology Audit and Production Reserves, 5 (1 (61)), 41-45. doi: http://doi.org/10.15587/2706-5448.2021.240260

\section{Introduction}

With the increase in the depth of mining in the conditions of coal mines of all countries of the world, the problem of ensuring the operational state of preparatory workings, which depends on a large number of mining and mining technical factors, is becoming more and more difficult. In order to reduce the cost of carrying out workings, as well as ensuring high loads on longwalls, special attention is paid to development systems with reuse of workings and efficient ventilation schemes for excavation areas [1-3]. Therefore, much attention is paid to the development and improvement of technology, methods and means of protecting the development workings behind the working faces [4-6].

All over the world, the development workings behind the rows are mainly guarded in the massif and by the pillars of coal, as discussed in the works [7-9]. But there are conditions when the abandonment of coal pillars to protect workings is unacceptable due to:

- significant losses of mineral resources [10-12];

- or the tendency of coal to ignite spontaneously [13,14].
In such cases, technologies are used when artificial structures made of wood, concrete, common rocks, and the like are used instead of pillars. The designs of such structures are considered in works $[12,15,16]$. It is obvious that these structures should be technological, low-cost and provide effective protection of mine workings. The cheapest in terms of material costs are means of protection, provide for the use of an ordinary breed. But because of their significant compliance, they cannot be considered effective. Therefore, it is necessary to improve them in order to reduce their flexibility and increase the bearing capacity.

Rubble band is a traditional means of protection based on the use of an ordinary breed [17-19]. The possibility of leaving rock in the mine has influenced the popularity of this technology. Practice has proven that rubble strips are cheaper than other technological means for the mechanization of their construction, and the initial costs are compensated by a decrease in the cost of maintaining mine workings and the cost of rock utilization. But these structures have disadvantages, which should be attributed: a large volume of rock, a high proportion of manual labor 
during its movement and presentation, low bearing capacity and great flexibility. These shortcomings induce to find new engineering solutions to increase the bearing capacity of the strips with a decrease in the required volume of rock. Therefore, studies on the effectiveness and parameters of the reinforcement of rubble strips are relevant.

A lot of inventions, for which in the nineties of the last century, the USSR author's certificates were obtained, have been forgotten in vain due to the fact that the Soviet Union no longer exists. In this work, some technical solutions are given, for which copyright certificates of the USSR and patents of Ukraine were obtained, but which, for various reasons, were never applied.

Today, it is important to communicate these ideas and proposals to a wide range of scientists, mining engineers and practitioners. Their use at the present time would make it possible to improve, as well as significantly improve the technology of mining solid minerals both in open pits and in coal mines. Therefore, it is relevant to improve the technologies for the development of deposits and the extraction of solid minerals by underground and open-pit methods by applying the existing original technical solutions, which are currently advisable to use in practice.

Thus, the object of research is the technological processes of the development of deposits and the extraction of solid minerals by underground and open-pit methods. Improvement of technological processes is achieved through the use of existing original technical solutions, which are currently advisable to use in practice. So, the aim of research is to analyze, select and substantiate the feasibility of applying in the appropriate mining-geological and mining-technical conditions of the available technical solutions to increase the efficiency of the development of mineral deposits.

\section{Methods of research}

The paper provides an analytical review of some technical solutions that can contribute to improving the technology of mining solid minerals in the development of deposits by both underground and open-pit mining.

\section{Research results and discussion}

First, let's consider the creation of more favorable technical conditions for the development of coal seams by applying new methods of development and excavation of both shallow and steep coal beads. For example, in [20], a method is proposed for the development of shallow thin coal seams of alternate excavation of the seam in two rows, separated by an artificial pillar and the collapse of the roof in the excavated space, which differs in that in order to increase the efficiency of development by reducing the harmful effects of primary the primary collapse of the roof in the excavated space of the first bench produces the destruction of the artificial pillar. And then they work off the second longwall from the excavated space.

A method of developing inclined coal seams [21] by drilling from a haulage to a ventilation drift of wells into the soles of the seam, followed by cutting the extraction pillars. When mining inclined and steep coal seams, the pillars are oriented by fall or uprising. When mining horizontal formations, the pillars are delineated by wells, which are oriented both along the strike and along the dip.
Then, vertical slots are drilled from these wells from the bottom to the top of the formation to the full depth of the column. The pillars outlined with slots are cut along the bottom of the formation. Thus, a gap is created in the bottom of the formation. A tape is inserted into this slot in the form of a loop with a one-sided anti-friction coating. Then the pillars are trimmed along the entire length of the pillar. As the coal is cut, it falls onto the belt. The strip with coal is pulled out onto the drift, and the spent space is fixed with a fastener.

A method of developing steep seams prone to sudden outbursts of coal and gas [21] by carrying out field drifts, from which cross-slugs are constructed at intervals equal to $2 / 3$ of the length of the bearing pressure zone on the seam. A rock plug is formed between the bottom hole and the formation and boreholes are drilled through the plug for the entire thickness of the formation. After that, the development of the formation is carried out in advance. When the line of stope excavation approaches the line of the borehole alignment, charges are detonated in these boreholes in the zone of maximum reference pressure. There is a destruction of plugs in the mouths and coal is poured out onto the crosscut and drift.

In [22], a technical solution is given as to how, at the stage of detailed additional exploration of a mine field, it is possible to control the state of the rock mass in the vicinity of a longwall cut from the face of the earth. A technology and methodology for calculating the location of unloading wells is proposed for carrying out a set of works on the preparation and bringing to a safe state of the rock mass of an important hard-to-fall roof in order to create conditions for the use of conventional mechanized coal complexes for the extraction and production of coal. The proposed technique makes it possible to increase the safety of mining operations and obtain a significant economic effect.

In [23], the geomechanical state of rocks in the vicinity of a preparatory mine working was studied and the mechanism of the formation of the load on it was determined. The analysis of various structures of fastening of preparatory workings is carried out, taking into account the properties of the security elements used. It has been established that when using an arched compliant threelink or even a five-link fastening, it is inappropriate to use rigid security elements such as blocks of reinforced concrete slabs, or rows of organ wooden fasteners, and so on. And, conversely, when using a rigid structure for supporting a development working (for example, a trapezoidal fastening made of reinforced concrete racks and an I-beam), it is inappropriate to use a rubble band or a «fire» as security elements, since such a structure will not give a positive effect. Therefore, to ensure a stable state of fastening of development workings located in the bearing pressure zone, it is necessary to use adaptive modular security elements of variable stiffness. The parameters and rigidity of modular security elements are calculated in each specific case, depending on the conditions of their load. Therefore, it is proposed to revise the existing standard schemes of protective elements of preparatory workings, which are still used in the mines of Ukraine, in order to ensure the stability of mine workings.

It is well known that explosive energy is used in openpit mines to break up hard rock. At the same time, with the help of various drilling rigs, several rows of wells are 
drilled, then they are charged and blasted. Currently, there is a wide variety of borehole diameters that are undermined, the designs of the borehole charges themselves, the schemes of their placement on the bench, the order of blasting, the deceleration time when the charges are detonated, etc. But with this diversity, there is one negative factor common to all cases: only half of the energy of the borehole explosive charges is used, and the other half uselessly goes into the depths of the rock mass, without participating in its destruction.

To illustrate the stated principle of using rock layers as screens, let's consider an array of inhomogeneous rock and semi-rock, composed of three different layers (Fig. 1) [24].

Rock layer 1 with high strength indices, which is limited from above and below by rock layers 2 and 3 with different physical and mechanical properties from it and from each other. When a borehole charge of an explosive located in layer 1 explodes, a longitudinal blast wave is formed.

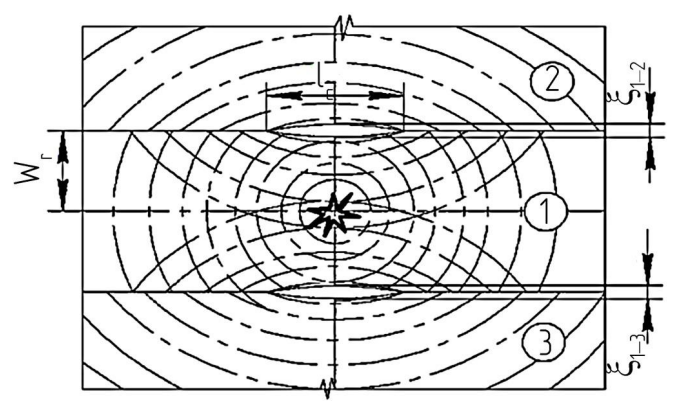

Fig. 1. Diagram of the mechanism of destruction of a heterogeneous rock mass by an explosion: 1, 2, 3 - rock layers with different physical and mechanical properties

The maximum displacement velocity in the shock front [24] is:

$$
U_{R \max }=\frac{\sigma_{R \max }}{\rho C_{p}} \cdot g
$$

where $\sigma_{R \max }-$ maximum compression stress; $\rho C_{p}$ - acoustic hardness of the rock; $g$ - acceleration of gravity.

The size of rock landslides during the action of a blast wave with a compression phase of duration $\tau$ is equal to:

$$
\xi=\int_{0}^{\tau} U_{R \max }(t) d t .
$$

Since the magnitude of the displacement for different rocks is not the same, then at their contact, layers break with the formation of a crack, with a thickness:

$$
\Delta \xi_{1-2}=\left|\xi_{1}-\xi_{2}\right|, \quad \Delta \xi_{1-3}=\left|\xi_{1}-\xi_{3}\right| .
$$

The width of the contact affected zone by a crack is determined by the formula:

$$
l_{C}=2 \sqrt{R_{0}^{2} \cdot \frac{\sigma_{0}}{[\sigma]} \cdot \sqrt[3]{\frac{\sigma_{0}}{[\sigma]}}-W_{r}^{2}}
$$

where $\sigma_{0}$ - stresses arising from the explosion of a cylindrical charge, radius $R_{0} ;[\sigma]$ - ultimate compressive strength of the rock; $W_{r}$ - reduced line of least resistance.
A mechanism is proposed for using this part of the previously unused energy of borehole explosive charges for additional high-quality destruction of rocks. This is achieved by sequentially using two different types of explosives. First, the first explosive is detonated in the drilled wells, which should transfer the largest part of the explosion energy to the rock mass. At the same time, for the maximum transfer of the explosion energy to the rock mass, the condition must be met: the acoustic stiffness of the rocks to be destroyed must be identical to the impedance of the explosive used. With further detonation, it is necessary to use a second explosive, which in its impedance should differ from the first explosive. This will allow, thereby, to exclude the previously accumulated potential energy, which was stored in the rock mass from previous explosions, in order to increase the destruction of the rock mass. This effect is achieved by the fact that the next wells are charged with an explosive, the impedance of which must also be equal to the acoustic stiffness of the rock and at the same time differ from the impedance of the previous explosive by one half-wave of compression.

With such an undermining, the destruction of rocks occurs due to the action of tensile stresses. And the tensile strength of rocks is an order of magnitude less than the compressive strength of rocks.

As a result of the analysis of the ecological situation in the industrial regions of Ukraine (Donetsk and LvivVolyn coal basin), it was found that about 500,000 hectares of land are currently under waste dumps of coal mines, quarries, processing plants and thermal power plants. And, approximately, about 300 waste heaps of Donbas continue to burn even at the present time, thereby polluting the atmosphere and worsening the ecological situation. More than 1.5 billion tons of rock mass is mined annually from the bowels of Ukraine, from which, after the extraction of useful components, $60-70 \%$ is transferred to waste dumps. Up to 1.5-2.0 thousand hectares of agricultural land are allotted annually for the placement of dumps. In Ukraine, there are more than 20 billion tons of mining waste in dumps. The problem of utilization of man-made raw materials is especially acute in the industrially developed Donbas, in the structure of the economic complex of which the coal industry is one of the leading industries. The specificity of underground coal mining in Donbas is that for every 1000 tons of mined coal there are up to 800 tons of waste rock. On the territory of Donbas there are more than 1,200 mine dumps (waste heaps), the area of which is 5,000 hectares, and taking into account the sanitary protection zone, about 30,000 hectares. At the same time, the annual volume of rock mass discharged into dumps is about 30 million $\mathrm{m}^{3}$, and their total volume in the region exceeds 2 billion $\mathrm{m}^{3}$, which, of course, creates significant environmental stress.

About $40 \%$ of the lands of Ukraine disturbed by mining are concentrated on the territory of Donetsk and Lugansk regions. These are dumps of coal mines, processing plants, metallurgical plants, thermal power plants, quarries for the extraction of building stone, refractory clays, sand, fluxes, etc. dirt and dust. Only, as mentioned above, in the Donbas there are about 1200 waste heaps from coal mines, of which almost 300 waste heaps continue to burn constantly.

The study of the composition of rock anthracite dumps and waste heaps showed that their ash part is represented mainly by $\mathrm{SiO}_{2}$ (up to $70 \%$ ), $\mathrm{Al}_{2} \mathrm{O}_{3}$ (up to $30 \%$ ) and 
$\mathrm{Fe}_{2} \mathrm{O}_{3}$ (up to $25 \%$ ). The content of basic oxides, alkalis and other elements does not exceed $5 \%$. These oxides are not found in free or pure form; in ash, they are usually represented by complex minerals: mudstone, carbonaceous mudstone, siltstone, sandstone, carbonates, etc.

The situation is ripe when it is necessary to stop creating new dumps and waste heaps, and to start complex processing of rocks of existing dumps with their subsequent complete elimination. It is not advisable to simply plant heaps with trees, since the land under dumps and waste heaps remains removed from the turnover of the country's agricultural land.

Based on the foregoing, microbiological reclamation was proposed to resume the process of soil formation [23]. It is proposed, when carrying out microbiological reclamation of lands disturbed by mining operations, to create a fertile soil layer directly from rocks, which represent dumps of open pits and waste heaps of coal mines.

The essence of such microbiological reclamation is that the pre-planned surface of the dump or waste heap is first treated with industrial waste that contains organic matter, and then treated with strains of microorganisms of nodule bacteria. After that, the areas are sown with seeds of perennial legumes. The process of interaction between rhizobacteria and leguminous plants begins at various stages of the formation of symbiosis. And already in 2-3 years on these areas from rocks of dumps and waste heaps the process of formation of a fertile soil layer takes place.

The newest technologies proposed in this work are limited by the mining-geological and mining-technical conditions of their application. Further improvement of technologies requires their adjustment after practical testing and application in the conditions of operating mining enterprises both in Ukraine and in other countries of the world.

\section{Conclusions}

This paper proposes some technical solutions to improve the technology for the development of deposits and the extraction of solid minerals. For underground mining of mineral deposits, methods of mining coal seams and methods of developing shallow coal seams are proposed for practical application [20, 21]. A method for controlling a hard-to-fall roof from the surface of the earth [22] is proposed for the appropriate conditions of occurrence of coal seams. The method of protecting preparatory mine workings by modular adaptive security elements of variable stiffness [23] is advisable to use to maintain mine workings in working order for the duration of the coal seam mining.

\section{References}

1. Bondarenko, V., Symanovych, H., Kicki, J., Barabash, M., Salieiev, I. (2019). The influence of rigidity of the collapsed roof rocks in the mined-out space on the state of the preparatory mine workings. Mining of Mineral Deposits, 13 (2), 27-33. doi: http://doi.org/10.33271/mining13.02.027

2. Gong, P., Ma, Z., Zhang, R. R., Ni, X., Liu, F., Huang, Z. (2017). Surrounding Rock Deformation Mechanism and Control Technology for Gob-Side Entry Retaining with Fully Mechanized Gangue Backfilling Mining: A Case Study. Shock and Vibration, 2017, 1-15. doi: http://doi.org/10.1155/2017/6085941

3. Nehrii, S., Sakhno, S., Sakhno, I., Nehrii, T. (2018). Analyzing kinetics of deformation of boundary rocks of mine workings. Mining of Mineral Deposits, 12 (4), 115-120. doi: http://doi.org/ $10.15407 /$ mining12.04.115
4. Shi, X., Jing, H., Ning, J., Zhao, Z., Zhu, J. (2020). Stability Control of Gob-Side Entry Retaining in Fully Mechanized Caving Face Based on a Compatible Deformation Model. Computer Modeling in Engineering \& Sciences, 124 (1), 315-343. doi: http://doi.org/10.32604/cmes.2020.07955

5. Qi, F., Ma, Z. (2019). Investigation of the Roof Presplitting and Rock Mass Filling Approach on Controlling Large Deformations and Coal Bumps in Deep High-Stress Roadways. Latin American Journal of Solids and Structures, 16 (4) doi: http://doi.org/10.1590/1679-78255586

6. Iordanov, I., Novikova, Y., Simonova, Y., Korol, A., Podkopayev, Y., Kayun, O. et. al. (2020). Determining stability conditions for haulage drifts protected by coal pillars. EasternEuropean Journal of Enterprise Technologies, 6 (1 (108)), 72-81. doi: http://doi.org/10.15587/1729-4061.2020.216530

7. Zhou, P., Wang, Y., Zhu, G., Gao, Y. (2019). Comparative analysis of the mine pressure at non-pillar longwall mining by roof cutting and traditional longwall mining. Journal of Geophysics and Engineering, 16 (2), 423-438. doi: http://doi.org/10.1093/jge/gxz026

8. Galvin, J. M. (2016). Ground Engineering - Principles and Practices for Undeground Coal Mining. New York, London: Springer International Publishing Switzerland, 684. doi: http:// doi.org/10.1007/978-3-319-25005-2

9. Feng, G., Wang, P., Chugh, Y. P., Zhao, J., Wang, Z., Zhang, Z (2018). A Coal Burst Mitigation Strategy for Tailgate during Deep Mining of Inclined Longwall Top Coal Caving Panels at Huafeng Coal Mine. Shock and Vibration, 2018, 1-18. doi: http://doi.org/10.1155/2018/5929785

10. Mishra, B., Tang, X. (2015). Stability analyses of bleeder pillars in longwall mines by displacement-discontinuity method. International Journal of Mining Science and Technology, 25 (6), 933-941. doi: http://doi.org/10.1016/j.ijmst.2015.09.009

11. Ngwenyama, P. L., de Graaf, W. W., Preis, E. P. (2017). Factors and challenges affecting coal recovery by opencast pillar mining in the Witbank coalfield. Journal of the Southern African Institute of Mining and Metallurgy, 117 (3), 215-222. doi: http://doi.org/10.17159/2411-9717/2017/v117n3a2

12. Skrzypkowski, K. (2020). Decreasing Mining Losses for the Room and Pillar Method by Replacing the Inter-Room Pillars by the Construction of Wooden Cribs Filled with Waste Rocks. Energies, 13 (14), 3564. doi: http://doi.org/10.3390/en13143564

13. Yu, Z., Wen, H., Chen, X., Zhang, C. (2018). Integrated Approaches forExtinguishing the Fire of Coal Pillars in Contiguous Coal Seams. Procedia Engineering, 211, 963-971. doi: http:// doi.org/10.1016/j.proeng.2017.12.098

14. Szurgacz, D., Tutak, M., Brodny, J., Sobik, L., Zhironkina, O. (2020). The Method of Combating Coal Spontaneous Combustion Hazard in Goafs - A Case Study. Energies, 13 (17), 4538 doi: http://doi.org/10.3390/en13174538

15. Wang, X., Xie, J., Xu, J., Zhu, W., Wang, L. (2021). Effects of Coal Mining Height and Width on Overburden Subsidence in Longwall Pier-Column Backfilling. Applied Sciences, 11 (7), 3105. doi: http://doi.org/10.3390/app11073105

16. Zhao, H. (2019). State-of-the-art of standing supports for gob-side entry retaining technology in China. Journal of the Southern African Institute of Mining and Metallurgy, 119 (11), 891-906. doi: http://doi.org/10.17159/2411-9717/17/449/2019

17. Gao, Y., Liu, D., Zhang, X., He, M. (2017). Analysis and Optimization of Entry Stability in Underground Longwall Mining. Sustainability, 9 (11), 2079. doi: http://doi.org/10.3390/su9112079

18. Skrzypkowski, K. (2020). Comparative Analysis of the Mining Cribs Models Filled with Gangue. Energies, 13 (20), 5290. doi: http://doi.org/10.3390/en13205290

19. Wang, X., Xie, J., Xu, J., Zhu, W., Wang, L. (2021). Effects of Coal Mining Height and Width on Overburden Subsidence in Longwall Pier-Column Backfilling. Applied Sciences, 11 (7), 3105. doi: http://doi.org/10.3390/app11073105

20. Tischenko, V. A., Novak, A. I., Okalelov, V. N., Belozertsev, V. N., Podtykalov, A. S., Antiukhov, S. V. (1986). Avt. sv-vo SSSR No. 1244316. Sposob razrabotki pologikh tonkikh ugolnykh plastov. Gosudarstvennii komitet SSSR po delam izobretenii i otkrytii. B. I. No. 26.

21. Belozertsev, V. N., Tischenko, V. A., Novak, A. I., Okalelov, V. N., Antiukhov, S. V. (1987). Avt. sv-vo SSSR No. 1330314. Sposob razrabotki krutykh plastov, sklonnykh $k$ vnezapnym vybrosam uglia $i$ gaza. Gosudarstvennii komitet SSSR po delam izobretenii i otkrytii. B. I. No. 30. 15.08.1987. 
22. Novak, A. I., Belozertsev, V. N., Tischenko, V. A., Okalelov, V. N (1988). Avt. sv-vo SSSR No. 1401130. Sposob upravleniia trudnoobrushaemoi krovlei. Gosudarstvennii komitet SSSR po delam izobretenii i otkrytii. B. I. No. 21. 07.06.1988

23. Novak, A. I. (2019). Pat. No. 136031 UA. Sposib ruinuvannia hirnychykh porid oybukhom. MPK: F42D 3/04 (2006.01). No. u201902516. declareted: 14.03.2019; published: 25.07.2019 Bul. No. 14.

24. Novak, A. I., Semeniuk, V. V. (2020). Pat. No. 139694 UA. Sposib rekultyvatsii zemel, porushenykh hirnychymy robotamy. No. u201907716. declareted: 08.07.2019; published: 10.01.2020, Bul. No. 1.

$\triangle$ Anatolii Novak, PhD, Associate Professor, Department of Organization and Production Automation, Technical University Metinvest
Polytechnic, Mariupol, Ukraine, ORCID: https://orcid.org/00000003-4852-3233,e-mail: Anatoliy.Novak@mipolytech.education

Eduard Fesenko, PhD, Associate Professor, Department of Organization and Production Automation, Technical University Metinvest Polytechnic, Mariupol, Ukraine, ORCID: https://orcid.org/00000002-7641-642X

Yevhen Pavlov, PhD, Associate Professor, Department of Organization and Production Automation, Technical University Metinvest Polytechnic, Mariupol, Ukraine, ORCID: https://orcid.org/00000002-3662-0477

$\triangle$ Corresponding author 